\title{
Effect of Open Refuse Dumpsite on the Quality of Underground Water Used for Domestic Purposes in Ado-Ekiti, Nigeria - A Public Health Awareness Study
}

\author{
David, O. M., \& Oluyege, A. O. \\ Department of Microbiology, Ekiti State University Ado-Ekiti, Nigeria \\ E-mail: davidoluwole5@gmail.com
}

Received: June 15, 2014 Accepted: June 20, $2014 \quad$ Published: August 29, 2014

doi:10.5296/jee.v5i2.6241ＵRL: http://dx.doi.org/10.5296/jee.v5i2.6241

\begin{abstract}
The quality of underground water is compromised by the indiscriminate dumping of waste in the environment and contamination by leachate. The effect of the dunghill leachate on the physicochemical and microbial quality of water samples collected from closest wells to the municipal waste disposing sites were investigated using standard chemical and microbiological methods. Different antibiotics (amoxicillin, amoxicillin clavulanic acid, chloramphenicol, cloxacillin, cotrimoxazole, erythromycin, gentamicin, nalidixic, nitrofurantoin, ofloxacin, streptomycin and tetracycline) were screened against two indicator organisms (Enterococcus faecalis and Escherichia coli) isolated from water samples. The distances of the wells from the foot of the nearby dump sites ranges from 85.3 to $25.7 \mathrm{~m}$. The $\mathrm{pH}$ values of the water samples ranged between 5.86 and 7.84. The turbidity of the water samples was also between 1.0 and 8.0 NTU. Five heavy metals were detected in the water samples with zinc having the highest value. The observed concentrations of metals in the wells water samples were presented as $\mathrm{Zn}>\mathrm{Pb}>\mathrm{Cu}>\mathrm{Co}>\mathrm{Hg}$. The total bacterial count of the water samples from the well ranged between $2.2 \times 10^{1} \mathrm{cfu} / \mathrm{ml}$ and $2.51 \times 10^{2} \mathrm{cfu} / \mathrm{ml}$ while the coliform load ranged from $9.1 \times 10^{1} \mathrm{cfu} / \mathrm{ml}$ and $1.3 \times 10^{1} \mathrm{cfu} / \mathrm{ml}$. Cloxacillin and tetracycline were not effective against the most of the E. faecalis isolates. Only $48(71.66 \%)$ and 53 $(88.33 \%)$ E. faecalis strains were sensitive to cloxacillin and tetracycline, respectively. Gentamicin was most effective on E. faecalis. Out of the eight antibiotics tested, ofloxacin was most effective against the pathogen. The quality of the water samples were below the tolerable level and unfit for domestic purposes.
\end{abstract}

Keywords: Dumpsites, Well, Enterococcus faecalis, Escherichia coli, Heavy metals, Indictor organisms, Antibiotic resistance 


\section{Introduction}

Most Nigerian cities are epitome of urban decay and characterized by poor housing, sanitation and public health infrastructure (Akinbiyi, 1992). Their erratic growth of housing units coupled with rapid population explosion has resulted in environmental health hazards (Adefemi \& Awokunmi, 2009).

Wastes are generated from human activities and in most cases not properly managed (Aurangabadkar et al., 2001) in most Nigerian cities (Adefemi \& Awokunmi, 2009). This leads to low environmental quality which accounts for $25 \%$ of all preventable ill health in the world (WHO, 2002). In most cases, wastes are collected and disposed off in uncontrolled dumpsite sited near residential buildings. These wastes are heaped up and/or burnt, polluting water resources and air (Akpan, 2004; Uffia et al., 2013).

Waste generally leads to proliferation of pathogenic microbes and heavy metals which can transfer significantly to the environment (Adefehinti, 2001). Leachates from dumpsites constitute a source of heavy metal pollution to both soil and aquatic environments (Ali \& Abdel-Satar, 2005). This may have detrimental effects on soils, crop and human health (Bahnasawy et al., 2011).

Most human activities revolve round water, and its quality in a long way affect health and the socio-economic development of man. Anthropogenic factors contribute highly to contamination of both surface and underground water (Singh \& Mosley, 2005). Water contaminants have been mainly biological and chemical in origin (Smith, 2003; Uffia et al., 2013). The quality of underground water could be compromised if it is not distant from constant source of pollution.

Like many cities in Nigeria, Ado-Ekiti is faced with the problems of improper collection, handling and disposal of domestic wastes. The aim of this work is to determine the effects of waste dumpsites within Ado-Ekiti metropolis on the physicochemical properties of the nearest wells and the antibiotic resistance of the indicator bacteria isolated from the water.

\section{Materials and Methods}

\subsection{Study Area and Collection of Water Samples}

Twenty different sites for dumping of the domestic wastes were identified within Ado-Ekiti metropolis $\left(7^{\circ} 40^{\prime} \mathrm{N}, 5^{\circ} 15^{\prime} \mathrm{E}\right)$. Water samples were collected aseptically using sterile sampling bottles from the nearest well to each of the dumpsites. The distance between the well and the feet of the dumpsites, and the depth of the well was measured to the nearest meter.

\subsection{Determination of Physicochemical and Heavy Metal Content of the Well Water}

Water samples were collected in sterile water plastic containers and were taken to the laboratory and analyzed within $3 \mathrm{~h}$ of collection. Freshly prepared doubled distilled water was used as control. Water samples were analyzed for physiochemical qualities according to AOAC (2005). Temperature was measured at the point of collection using a Digitron 
Thermometer (Model 275-K). Electrical conductivity was measured with a CDM 83 conductivity meter (Radio Meter A/S Copenhagen, Denmark). Turbidity and $\mathrm{pH}$ were determined at site using Water Proof Scan 3+ Double Junction (Wagtech International, UK). The level of heavy metals $(\mathrm{Co}, \mathrm{Cu}, \mathrm{Hg}, \mathrm{Pb}$ and $\mathrm{Zn})$ in the well water samples were determined by atomic absorption spectrophotometry, Model 403 (Perkin-Elmer, Norwalk, Connecticut, USA). All determinations were made in duplicate.

\subsection{Isolation and Identification of Bacterial Isolates}

Water samples were collected from wells in sterile containers, from all the located wells. In a sterile environment one milliliter of the samples was introduced into $9 \mathrm{ml}$ of sterile distilled water and gently agitated after which a 10 fold serial dilutions were carried out. One $\mathrm{ml}$ of appropriate dilution was aseptically plated, using pour plate technique, on Plate count agar (Oxoid), Bile aesculin azide agar (Oxoid) and MacConkey agar (Oxoid) to determine the total bacterial count, enterococcal load and coliform load respectively. Colonies with dark brown to black hallow on Bile aesculin azide and those with greenish metallic sheen on MacConkey agar were characterized and identified using colonial, morphological and biochemical characteristics as described by Holt et al. (1994).

\subsection{Antibiotic Sensitivity Testing}

The isolates were grown at $37^{\circ} \mathrm{C}$ in Mueller-Hilton broth (Oxoid) for $18 \mathrm{~h}$ and diluted to an optical density of 0.1 ( $0.5 \mathrm{McFarland}$ Standard) and stored at $4{ }^{\circ} \mathrm{C}$. The disc diffusion method was used for susceptibility testing as described by Clinical and Laboratory Standard Institute (2008). The isolates were tested against eight commercial antibiotic disks (Abtek Biologicals Limited) which their concentrations in microgram in the discs were as follows: amoxicillin (25), gentamicin (10), cotrimoxazole (25), amoxicillin clavulanic acid (30), streptomycin (100), tetracycline (30), chloramphenicol (30), cloxacillin (5), erythromycin (15), ofloxacin (30), nitrofurantoin (100) and nalidixic (30).

\section{Results}

Effect of dumpsite leachate on the physicochemical, mineral and microbial qualities of underground water samples collected from twenty closest wells to municipal waste disposing sites were investigated. The distances of the wells from the foot of the nearby dump sites ranges from 85.3 to 25.7 as shown in Table 1. Most of the physicochemical parameters of the water from the wells were within the acceptable limits of both World Health Organization and Nigerian Standard for Drinking Water Quality for drinking water. The $\mathrm{pH}$ values of the water ranged between 5.86 and 7.84. The turbidity of the water samples was between 1.0 and 8.0 NTU. The values of hardness and sulphate in the water samples were higher than the Nigerian Standard for Drinking Water Quality. 
Table 1. Attributes of nearest wells to dumpsites in Ado-Ekiti

\begin{tabular}{|c|c|c|c|c|c|}
\hline Location & $\begin{array}{l}\text { Distance from } \\
\text { Dumpsite (m) }\end{array}$ & $\begin{array}{c}\text { Depth of } \\
\text { the well }(\mathrm{m})\end{array}$ & $\begin{array}{l}\text { Well } \\
\text { ringing } \\
\text { status }\end{array}$ & $\begin{array}{l}\text { Well } \\
\text { covering } \\
\text { status }\end{array}$ & $\begin{array}{l}\text { Fetcher } \\
\text { type }\end{array}$ \\
\hline Agric & 69.2 & 12.8 & Ringed & Covered & Single \\
\hline Bawa road & 77.1 & 11.4 & Not ringed & Covered & Single \\
\hline Idemo & 85.3 & 13.6 & Ringed & Covered & Single \\
\hline Idolofin & 47.4 & 10.1 & Not ringed & Not covered & Multiple \\
\hline Ijiku & 83.8 & 15.5 & Ringed & Covered & Single \\
\hline Isato & 50.6 & 8.8 & Ringed & Covered & Single \\
\hline Kajola & 28.2 & 11.4 & Not ringed & Covered & Multiple \\
\hline Mary & 40.5 & 10.6 & Not ringed & Covered & Multiple \\
\hline \multicolumn{6}{|l|}{ Immaculate } \\
\hline Odo-Aremu & 72.8 & 8.2 & Plastered & Covered & Multiple \\
\hline Odo-Iremo & 68.2 & 13.3 & Ringed & Covered & Multiple \\
\hline Oke-Age & 26.7 & 10.5 & Ringed & Covered & Multiple \\
\hline Oke-Apoko & 35.3 & 8.6 & Not ringed & Covered & Single \\
\hline Oke-ila & 44.6 & 12.1 & Not ringed & Covered & Multiple \\
\hline Oke-oriomi & 50.7 & 9.4 & Not ringed & Covered & Multiple \\
\hline Olobe L.A & 62.3 & 13.2 & Not ringed & Covered & Multiple \\
\hline Oloke-meji & 25.7 & 11.5 & Not ringed & Covered & Multiple \\
\hline Olokuta & 70.9 & 13.1 & Ringed & Covered & Multiple \\
\hline Progress FM & 58.2 & 14.8 & Ringed & Not covered & Multiple \\
\hline Secretariat road & 55.9 & 8.4 & Ringed & Covered & Single \\
\hline Simile l'Oluwa & 52.3 & 16.1 & Not ringed & Not covered & Multiple \\
\hline Mean & 55.29 & 11.67 & & & \\
\hline SD & 18.40 & 2.37 & & & \\
\hline CV\% & 33.2783 & 20.34 & & & \\
\hline
\end{tabular}

Table 2. Physico-chemical analyses of water samples from well sunk near dump sites in Ado-Ekiti

\begin{tabular}{lccc}
\hline Parameters & $\begin{array}{c}\text { Water samples } \\
\text { from well }\end{array}$ & NSDQW* & WHO** \\
\hline $\mathrm{pH}$ & $5.86-7.84$ & $6.5-8.5$ & $6.5-9.8$ \\
Chloride $(\mathrm{mg} / \mathrm{l})$ & $66.49-45.63$ & 250.0 & 250.0 \\
Hardness $(\mathrm{mg} / \mathrm{l})$ & $324.6-456.3$ & 150 & 500.0 \\
Sulphate $(\mathrm{mg} / \mathrm{l})$ & $235.0-522.0$ & 100.0 & 400.0 \\
Nitrate $(\mathrm{mg} / \mathrm{l})$ & $13.0-38.0$ & 50.0 & 50.0 \\
Turbidity $(\mathrm{NTU})$ & $1.0-8.0$ & 5.0 & 5.0 \\
Conductivity $(\mu \mathrm{s} / \mathrm{cm})$ & $12.2-23.4$ & 1000.0 & 20.0 \\
Total suspended Solid $(\mathrm{mg} / \mathrm{l})$ & $181.6-272.2$ & 500 & No Guideline value \\
Total alkalinity $(\mathrm{mg} / \mathrm{l})$ & $35.50-43.56$ & $30-500$ & $30-500$ \\
Cobalt $(\mathrm{mg} / \mathrm{l})$ & $0-0.10$ & Not stated & Not stated \\
\hline
\end{tabular}




\begin{tabular}{lccc}
\hline Copper $(\mathrm{mg} / \mathrm{l})$ & $0.01-0.10$ & 1.00 & 2.00 \\
Mercury $(\mathrm{mg} / \mathrm{l})$ & $0-0.01$ & 0.001 & 0.006 \\
Lead $(\mathrm{mg} / \mathrm{l})$ & $0.01-0.13$ & 0.01 & 0.01 \\
Zinc $(\mathrm{mg} / \mathrm{l})$ & $0.19-2.95$ & 3.00 & 5.00
\end{tabular}

NSDQW $=$ Nigerian Standard for Drinking Water Quality (2007)

$\mathrm{WHO}=$ World Health Organization Standard for drinking water

*Maximum Allowable Limits

Five heavy metals were detected in the water samples. Table 2 shows that zinc had the highest value among the heavy metals detected. Cobalt and mercury were not detected in some of the samples. All the heavy metals screened were within the WHO health based provisional range. The observed concentrations of metals in the wells water samples were presented as $\mathrm{Zn}>\mathrm{Pb}>\mathrm{Cu}>\mathrm{Co}>\mathrm{Hg}$. Though the wells were contaminated with heavy metals the values are within the acceptable values. The total bacterial count of the water samples from the well ranged between $2.2 \times 10^{1} \mathrm{cfu} / \mathrm{ml}$ and $2.51 \times 10^{2} \mathrm{cfu} / \mathrm{ml}$ while the coliform load ranged from $1.3 \times 10^{1}$ and $9.1 \times 10^{1} \mathrm{cfu} / \mathrm{ml}$. The enterococcal load was lower that the load of the $E$. coli in the entire water sample collected. The enterococci-coliform ratio was less than unity (1.00) in all the water from all the well samples (Table 3).

Table 3. Bacterial load of the wells water sunk near dumpsites in Ado-Ekiti (cfu/ml)

\begin{tabular}{lccccc}
\hline Sampling site & \multicolumn{5}{c}{ Bacterial load } \\
\cline { 2 - 6 } & Total & Coliform & E. coli & E. faecalis & $\begin{array}{c}\text { Enterococci-colifo } \\
\text { rm ratio }\end{array}$ \\
\hline Agric olope & 200 & 45 & 27 & 7 & 0.259 \\
Bawa Road & 202 & 89 & 10 & 3 & 0.300 \\
Idemo & 111 & 68 & 9 & 2 & 0.222 \\
Idolofin & 121 & 50 & 21 & 18 & 0.857 \\
Isato & 128 & 47 & 13 & 4 & 0.308 \\
Itikun & 251 & 52 & 20 & 4 & 0.200 \\
Kajola & 190 & 51 & 29 & 14 & 0.483 \\
Mary Immaculate & 98 & 37 & 13 & 8 & 0.615 \\
Odo-Aremu & 144 & 91 & 9 & 2 & 0.222 \\
Odo-Iremo & 156 & 84 & 23 & 5 & 0.217 \\
Oke-Age & 190 & 90 & 13 & 6 & 0.462 \\
Oke-Apoko & 217 & 41 & 24 & 2 & 0.083 \\
Oke-Ila & 82 & 13 & 9 & 2 & 0.222 \\
Oke-Oriomi & 48 & 21 & 21 & 4 & 0.190 \\
Olobe & 181 & 49 & 10 & 3 & 0.300 \\
Olokemeji & 22 & 17 & 8 & 6 & 0.750 \\
Olokuta Agric & 43 & 33 & 14 & 9 & 0.642 \\
Progress FM & 129 & 36 & 31 & 15 & 0.484 \\
Secretariat Road & 81 & 26 & 7 & 6 & 0.857 \\
Simil'Oluwa & 204 & 73 & 15 & 5 & 0.333 \\
\hline
\end{tabular}


Enterococcus faecalis $(\mathrm{n}=60)$ and E. coli $(\mathrm{n}=42)$ isolated from the water samples were subjected to antibiotic susceptibility test. Only $48(71.66 \%)$ and $53(88.33 \%)$ E. faecalis strains were sensitive to cloxacillin and tetracycline, respectively. Gentamicin was most effective on E. faecalis with $15.00 \%(\mathrm{n}=9)$ resistance. Each with $92.86 \%(\mathrm{n}=39)$ resistance, tetracycline and cotrimoxazole were not effective against $E$. coli strains from the water samples. Out of the eight antibiotics tested ofloxacin (23.81\% resistance) was most effective against the E. coli as shown in Table 4, followed by gentamicin with $40.48 \%(\mathrm{n}=17)$.

Table 4. Antibiotic resistance of the representative E. faecalis and E. coli isolated from the well water samples

\begin{tabular}{lcc}
\hline \multirow{2}{*}{ Antibiotics } & \multicolumn{2}{c}{ Indicator Organisms } \\
\cline { 2 - 3 } & E. faecalis (n=60) & E. coli $(\mathbf{n = 4 2})$ \\
\hline Amx & ND & $31(73.81 \%)$ \\
Amoclav & $39(65.00 \%)$ & $34(80.95 \%)$ \\
Chl & $42(70.00 \%)$ & ND \\
Cot & $35(58.33 \%)$ & $39(92.86 \%)$ \\
Cxc & $48(80.00 \%)$ & ND \\
Ery & $38(63.33 \%)$ & ND \\
Gen & $9(15.00 \%)$ & $17(40.48 \%)$ \\
Nal & ND & $29(69.05 \%)$ \\
Ofl & ND & $10(23.81 \%)$ \\
Nit & ND & $31(73.81 \%)$ \\
Tet & $53(88.34 \%)$ & $39(92.86 \%)$ \\
Str & $45(75.00 \%)$ & ND \\
ND $=$ Not determined & &
\end{tabular}

\section{Discussion}

Improper waste disposing system contributes immensely to the contaminations of groundwater. High turbidity of the water samples is due to the infiltration of leachate from the dumpsites into the wells as reported by Ogedengbe \& Akinbile (2007). The contaminants are largely soluble compounds and microorganisms (Aderiye et al., 1992; Udoessien, 2004), although the physical parameters of the water samples were within the recommended limits, heavy metals were detected in the water samples. The heavy metals could be from leachates from the dump sites as suggested by Akpan (2004). Heavy metals are not commonly found in water, their presence is largely as a result of environmental contamination (Bahnasawy et al., 2011). They get accumulated and affect different organs and caused several ailments in the body. Their amount in the water depends on $\mathrm{pH}$, temperature, water hardness, standing time of the water among other factors (IPCS, 2003; WHO, 2003). Urban wastes constitute a large source of pollution and have a significant impact on the ecosystem (Adebayo et al., 2007; Edema et al., 2001; Pirsaheb et al., 2013).

The entire well water sampled had a total bacterial and coliform load far above the minimum WHO allowable limits for drinking water. The high amount may be due to infiltration from faecal materials and decaying materials from the dumpsites (Balogun \& Longe, 1998). 
Although water is not a natural habitat for E. faecalis and E. coli, their presence in well water can be due to faecal contamination as a result of percolation (Wilson, 2005).

The indicamtors of feacal pollution: E. faecalis and E. coli play a significant role in intestinal and extra-intestinal diseases (Havelaar \& Nieuwstad, 1985). Peter et al. (2012) isolated enterococci in 76 out of 100 tested wells water and reported their presence to be as a result of feacal pollution. In this study the E. faecalis and E. coli isolated from the water samples from the wells were resistant to most first line antibiotics used in clinical practices. There is an increase in the resistance of the two organisms compared to the previous reports. Resistance of E. faecalis to amoxicillin/clavulanic acid increased $65 \%$ as against $43 \%$ reported by David et al. (2011). Also resistance to cotrimoxazole rose ranged from $36 \%$ to $58.33 \%$ in the recent study. Among the strains of $E$. coli resistance increased from $67 \%$ to $73.81 \%, 20 \%$ to $80.95 \%$ and $1 \%$ to $23.81 \%$ to amoxicillin, amoxicillin/clavulanic acid and ofloxacin, respectively. The variation in the resistance pattern may due to prior exposure to antimicrobial agents or heavy metals.

Apart for hardness and sulphate, the values of physicochemical parameters were within the set standard of Nigerian Standard for Drinking Water Quality. The nearness of the wells to the dumping sites affects the quality of the water from the wells. There is possibility of movement of resistant pathogens from the leachate from the dumpsites into the well. A relatively high prevalence of resistance among the indicator organisms to first line antibiotics than the previous reports was observed in this study.

\section{References}

Adebayo, O. T., Balogun, A. M., \& Olubiyi, O. A. (2007). Chemical analysis of some industrial effluents that discharge into Lagos Lagoon, Nigeria. Res. J. Environm. Sci., 1(4), 196-199. http://dx.doi.org/10.3923/rjes.2007.196.199

Adefehinti, O. A. (2001). Toxicity Testing of Stimulated Leachates of solids waste from Olusosun Landfill, Ojota, Lagos. M.Sc. Thesis, Chemistry Department, University of Ibadan, Ibadan, Nigeria. Pp. 104-105.

Adefemi, O. S., \& Awokunmi, E. E. (2009). The impact of municipal solid waste disposal in Ado-Ekiti metropolis, Ekiti State, Nigeria. Afri. J. Environ. Sci. Technol., 3(8), 186-189.

Aderiye, B. I., Igbedioh, S. O., \& Adebobuyi, A. A. (1992) Incidence of coliforms in well water and outbreak of water borne diseases: Environmental considerations and empirical evidence from Owo, Nigeria. Asia Mediterr di Patolog Infet. Tropic., 11, 1-6.

Akinbiyi, R. (1992). Improving the urban environment. Africa Health, 15(1), 112-124.

Akpan, A. Y. (2004). Physico-chemical studies on the pollution potential of Itu River, Akwa Ibom State, Nigeria. World J. Agric. Sci., 5(1), 1-4.

Ali, M. H., \& Abdel-Satar, A. M. (2005). Studies of some heavy metals in water, sediment, fish and fish diets in some fish farms in El-Fayoum province. Egypt. J. Aquat. Res., 31, 261-273. 
AOAC (Association of Official Analytical Chemistry). (2005). Official Methods of Analysis, $18^{\text {th }}$ edn. Section $12.1 .7 ; 968.08 ; 4.1 .28$, Association of Official Analytical Chemists, Washington DC.

Aurangabadkar, K., Swaminathan, S., Sandya, S., \& Uma, T. S. (2001). Impact of municipal solid waste dumpsite on ground water quality at Chennai, Environ. Poll. Control., 5, 41-44.

Bahnasawy, M., Khidr A., \& Dheina, N. (2011). Assessment of heavy metal concentrations in water, plankton, and fish of Lake Manzala, Egypt. Turk. J. Zool., 35(2), 271-280.

David, O. M., Akinwunmi, A., Oluduro, A. O., Egbebi, A. O., \& Famurewa, O. (2011). Antibiotic resistance and plasmid profile of bacterial pathogens isolated from drinking water in Ado-Ekiti, Nigeria. Nig. J. Microbiol., 25, 2339 - 2344.

Edema, M. O, Omemu, A. M., \& Fapetu, O. M. (2001). Microbiology and Physicochemical Analysis of different sources of drinking water in Abeokuta. Nigeria. Nig. J. Microbiol, 15(1), 57-61.

Hamed Y. A., Abdelmoneim T. S., ElKiki M. H., Hassan M. A., \& Berndtsson R. (2013). Assessment of heavy metals pollution and microbial contamination in water, sediments and fish of Lake Manzala, Egypt. Life Sci. J. 10(1), 86-99.

Havelaar, A. H., \&Nieuwstad, T. J. (1985). Bacteriophages and fecal bacteria as indicators of chlorination efficiency of biologically treated wastewater. J. Water Poll. Control Feder., 57, 1084-1088.

Holt, J. G., Krieg, N. R., Sneath, P. H. A., Staley, J. T., \& Williams, S. T. (1994). Bergey's Manual of Determinative Bacteriology (9th ed). Williams and Wilkins, Baltimore.

IPCS (International Programme on Chemical Safety). (2003) Elemental mercury and inorganic mercury compounds: human health aspects. Geneva, World Health Organization, International Programme on Chemical Safety (Concise International Chemical Assessment Document 50).

NSDQW (Nigerian Standard for Drinking Water Quality) (2007). Nigerian Industrial Standard NIS 554, Standard Organization of Nigeria. Pp. 15-17.

Ogedengbe, C., \& Akinbile, C. O. (2007). Well waters disinfection by solar radiation in Ibadan, Nigeria. Nig. J. Technolog. Develop., 5(1), 39-47.

Peter, A., Mathew, J., \& Zacharia, S. (2012). Antibiotic resistant enterococci from drinking water sources. Asian J. Pharmaceut. Clin. Res. 5(3), 158-160.

Pirsaheb, M., Khosravi, T., Sharafi, K., Babajani, L., \& Rezaei, M. (2013). Measurement of Heavy Metals Concentration in Drinking Water from Source to Consumption Site in Kermanshah - Iran. World Appl. Sci. J., 21(3), 416-423.

Singh, K. L., \& Mosley, H. B. (2005). Industrial Pollution and Implication on Source of Water Supply in Kano, Nigeria. Inter. J. Eng. Technol., 10(1), 101-110. 


\section{Macrothink}

Journal of Environment and Ecology

ISSN 2157-6092 2014, Vol. 5, No. 2

Udoessien, E. I. (2004). Ground Water and Surface Water Pollution by Open Refuse dump in Akwa Ibom State, Nigeria. J. Environ. Sci., 3(1), 24 - 31.

Uffia, I. D., Ekpo, F. E., \& Etim, D. E. (2013). Influence of heavy metals pollution in borehole water collected within abandoned battery industry, Essien Udim, Nigeria. J. Environ. Sci. Water Resources, 2(1), $022-026$.

WHO (World Health Organization) (2003). Lead in drinking-water. Background document for preparation of WHO Guidelines for drinking-water quality. Geneva, World Health Organization.

WHO (World Health Organization). (2002). Water, Sanitation and Hygiene. World Health Organization, Geneva.

Wilson, M. (2005). Microbial Inhabitants of Humans. Their Ecology and Role in Health and Disease, Cambridge University Press: Cambridge, UK. 